\title{
CERTFOR: A new sustainable forestry management standard for Chile's forest plantations
}

\author{
by F. Dubé ${ }^{1}$, G. Gignac ${ }^{1}$, M.I. Miranda² and E. Melo ${ }^{3}$
}

This technical paper reviews CERTFOR, the Chilean initiative for sustainable plantation forestry. Since its release in January 2002, 1.5 million ha of Pinus radiata and Eucalyptus species plantations have been certified as well managed, Forestal Arauco S.A. becoming the first company and major player with nearly $35 \%$ of total planted woodlands in Chile. QMI conducted the audits using a multidisciplinary international team. The structure of the standard includes 9 principles, 43 criteria and 190 indicators. In early 2004 , the PEFC started a public consultation period for the assessment of CERTFOR. Once completed, it will be the first non-European standard to be recognized by PEFC.

Key words: Arauco, certified forest plantations, CERTFOR, PEFC, QMI, stakeholder consultation, sustainable forest management practices

Cette publication technique analyse CERTFOR, la nouvelle norme chilienne pour l'aménagement durable des plantations forestières. Depuis son lancement en janvier 2002, 1.5 million d'hectares de Pinus radiata et Eucalyptus espèces ont été certifiés pour leurs pratiques saines et durables, Forestal Arauco S.A. devenant la première entreprise et plus grand joueur avec près de $35 \%$ de la superficie totale plantée au Chili. QMI a réalisé les audits utilisant une équipe internationale multidisciplinaire. La structure de la norme comprend 9 principes, 43 critères et 190 indicateurs. Au début 2004, le PEFC a initié la période de consultation publique pour la vérification de CERTFOR. Une fois complétée, elle sera la première norme non européenne à être homologuée par le PEFC.

Mots-clés : Arauco, CERTFOR, consultation publique, PEFC, plantations forestières certifiées, pratiques d'aménagement forestier durable, QMI

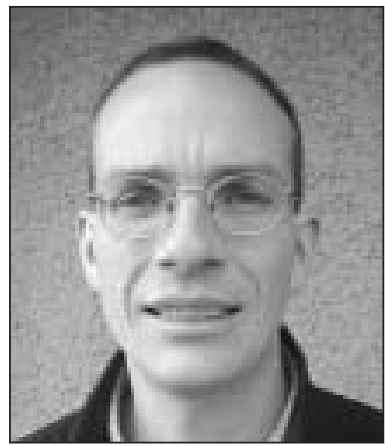

F. Dubé

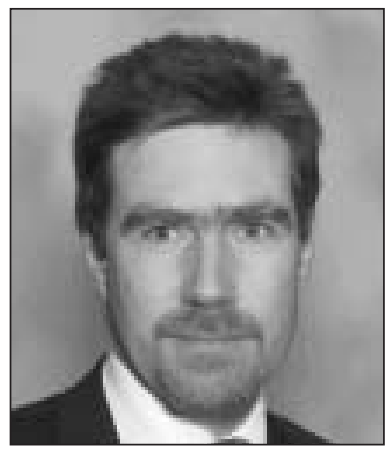

G. Gignac

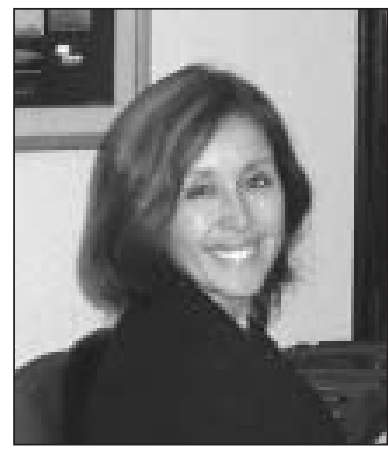

M.I. M iranda

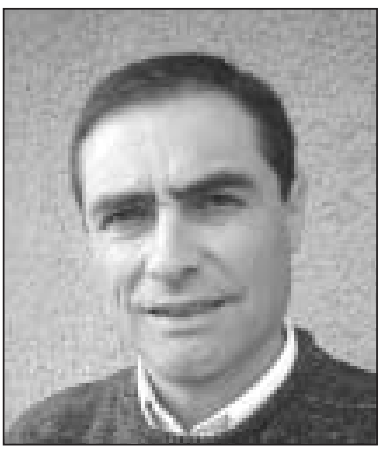

E. M elo

\section{Introduction}

Chile is a forestry country. Its total forest area covers about 15.5 million ha, or $21 \%$ of the national territory. Of these, 13.4 million ha are categorized as native forests while 2.04 million ha are plantations as defined by the Food and Agricultural Organization (FAO) ${ }^{4}$. The most commonly planted species are Pinus radiata (74\%), followed distantly by Eucalyptus globulus and Eucalyptus nitens (18\%) and a few other species such as Populus species for the remaining area. Overall, plantations represent $13.5 \%$ of the total forest cover and $2.8 \%$ of the country area.

\footnotetext{
${ }^{1}$ QMI- A Division of CSA Group, 865 Ellingham St, Pointe-Claire, Québec H9R 5E8. E-mail: fdube@qmi.com; ggignac@qmi.com

${ }^{2}$ CertforChile, Av. Parque Antonio Rabat Sur 6165, 766-0118 Vitacura, Santiago, Chile.E-mail: mmiranda@certfor.org

${ }^{3}$ Forestal Arauco S.A., Los Canelos 71 San Pedro de la Paz Casilla 70-C, Concepción, Chile. E-mail: emelo@arauco.cl
}

In August 2003, Chile's largest forest company, Forestal Arauco S.A., became the first organization to be certified to the CERTFOR SFM (sustainable forestry management) standard. Arauco Forestry Divisions in Chile, Forestal Celco, Forestal Cholguán, Bosques Arauco, and Forestal Valdivia, obtained their certification for 926900 ha of forest. The remaining CERTFOR certified forests were granted in 2004 and belong to Forestal Mininco S.A. (540 766 ha), Forestal y Agricola Monteaguila S.A. (59 514 ha) and Bosques de Chile S.A. (25 240 ha). With these new certifications, Chile now has 1.5 million ha, or $10 \%$ of its woodlands certified as well managed according to environmental, social and economic principles.

This achievement is a milestone for Arauco and the entire Chilean forestry sector. Several years ago, government, NGOs (non-governmental organizations) associated with the European Union, industry associations, forest industry companies and other concerned parties launched a collective effort to establish a Chilean SFM standard. 
As Arauco is committed to long-term forest management, its forestry operations are using economically viable technology to respect the environment and the affected community. Today, customers demand high-quality forestry products at competitive prices, but also require products to be environmentally friendly and socially acceptable.

The Canadian firm QMI, a Division of CSA Group, was chosen from among a number of contending international registrars authorized by CertforChile to conduct CERTFOR SFM certification audits of Forestal Arauco S.A. QMI's vast experience in SFM certification in North and South America contributed to its selection (QMI - A Division of CSA Group 2003a).

\section{History of the Standard}

The development of a series of criteria and indicators for plantation forestry in Chile started in 1999 as a research project conducted by the Instituto Forestal (INFOR). By late 1999 this project had developed a first draft series of criteria and indicators based on the Montreal Process. Nevertheless, what the industry needed at that time was a sustainable forest management certification standard adapted to the reality of the plantation forestry sector in Chile, taking into account the experience gathered by diverse public and private initiatives. This task called for the participation of all the principal stakeholders of the forest sector at the national level and of some well-known international organizations.

For this reason, in 2000 Fundación Chile and INFOR established a partnership to combine knowledge and experience in a project to create a National Standard based on the previous work made by INFOR. Fundación Chile was appointed as the process Secretary and was in charge of the management and the organization of the project. INFOR, co-partner in this project, was responsible for the technical aspects. CORFO, the Chilean Development Agency, sponsored more than 50\% of the project.

The actual standards development work started in January 2001. A first draft of the standard was ready for field test in May 2001. The revised draft standard was published for public consultation in September 2001. Two public consultation meetings were held in October 2001 and in January 2002. The Board finally approved the Standard in February 2002. The first certificate in Chile was issued to Arauco in October 2003 by QMI (see sidebar).

Ultimately, the system will depend on the auditing work companies accredited by the Chilean National Standards Organization (Instituto Nacional de Normalización (INN)) carried out according to the guidelines issued by CertforChile. It is expected that the first accreditations will be granted in 2004.

As an interim measure, the Board defined the following procedure for issuing certificates based on verifications carried out by auditing companies with international experience in auditing forest management systems. The audit teams must have members who have been trained by CertforChile in auditing the CERTFOR standard. In addition, the lead auditor should be an experienced forest management system auditor with ample

\footnotetext{
${ }^{4}$ According to FAO, forest plantations consist of intensely managed stands of either introduced or indigenous species (not exceeding one or two species at planting), regular spacing and even age class (Cashore and McDermott 2004).
}

experience in forest certification auditing in performance-based certification systems.

\section{Administration of the Standard}

The owner of the initiative is CertforChile, a not-for-profit, independent organization, recognized by the State and laws of the Nation, ruled by a Board, and with numerous members, representing a cross section of stakeholders from the environmental, university, forest industry companies, small private land owners, buyers groups, research organizations, and other private NGOs.

The Board has determined that the standard will be revised every five years in order to take into account advancements in science, technological improvements, changes in social and environmental concerns of stakeholders and changes in the legal and political situation in Chile. Accordingly, the certificates will be valid for five years. The running of the scheme is carried out by a secretariat, a function at present done by Fundación Chile.

\section{Basis for the Standard}

The following elements were taken into account in developing the CERTFOR Standard for Sustainable Forest Management in Chile: existing definitions of Sustainable Forest Management and international agreements such as the Montreal Process and the Principles and Criteria of the Forest Stewardship Council (FSC), the draft of the Standard developed by INFOR in December 2000, the concerns identified by international consultants during interviews organized with different stakeholders visited, the concerns of the environmentally sensitive markets, and the situation of the forestry sector in Chile.

The Standard is also based on several international standards (e.g., FSC, PEFC, CAN/CSA Z809-02) and seeks to establish procedures that agree with what is considered to be current sustainable forest management thinking, and also take into consideration the main concerns that have been raised by the different stakeholders with respect to plantation forestry in Chile. The Standard aims to generate a positive change in the way in which forest plantations are managed and not to focus on a few bureaucratic obligations. This is the reason why the principles, criteria and indicators developed in this Standard can be favourably compared with other respected international sustainable forest management standards.

\section{Objective and Structure of the Standard}

The Standard encourages organizations seeking certification to adhere to the specifications of internationally recognized sustainable forest management practices adapted to the national reality of Chile. Additionally, the standard will help to identify forest management entities that present an excellent level of performance. The hierarchical structure of the standard includes principles, criteria and indicators, which are described as follows (Canadian Standards Association 2002, CertforChile 2003a):

\section{Principles}

These are elements that define a conceptual framework, and whose function is to serve as a basis or guideline for activities contributing to the main objectives of sustainable management. They are seen as the ultimate long-term objectives of forest management. 
A two-tier organization for developing and ratifying the standard was agreed in 2000. The first tier consisted of a higher council of certification made up of well-respected members of Chilean society selected to represent a wide range of environmental, social and economic interests. The second tier is the technical committee for certification, a larger group of technical experts in a variety of fields.

The task of drafting a working standard was delegated to a team consisting of representatives of CORMA, Fundación Chile and INFOR under the Chairmanship of external consultant Dr. Hubertus J. van Hensbergen. The task team started its work in January 2001. Its work was based on the previous INFOR process. In addition to this, a first round of consultation with a variety of stakeholders (environmental and social NGOs, government agencies, forestry companies, indigenous people) was carried out by the external consultants in order to identify key issues for the development of a standard.

A draft standard and an auditor's manual were prepared by mid-May of 2001. These were field tested by two teams of auditors. Following the field test the draft was refined and in September 2001 a public meeting was held. At the same time the draft standard was released to the public as part of a more detailed consultation with interested and affected parties. This was followed up by a First Public Consultation Workshop held on October 26, 2001 with the participation of representatives with a wide spectrum of interests. These included several NGOs such as Greenpeace and CODEFF-Concepción, independent professionals, academics, international organizations such as the FAO, forestry workers representatives, native people, members of the Technical Committee of the Forest Certification Initiative, technical representatives of the National Standards Institute (INN), the Agriculture and Livestock Service (SAG), the Chilean Health and Safety Association (ACHS), the Chilean Forest Service (CONAF), the Forest Owners Association of Chile (CORMA), the Ministry of Agriculture, the Chilean Development Agency (CORFO), and the Forestry Institute (INFOR). The inputs from this consultation were carefully documented and the standard was revised in light of the comments received. A second public consultation was held in January 2002 and the standard was ratified by the Board after all consultations had been exhausted and all important issues had been resolved to their satisfaction.

The standard for plantations was developed by a consultative process in which stakeholders were repeatedly asked to comment on the standard proposal. Final approval of the standard was carried out by the Board.

1) Long-term forest planning: the use of the forest resources shall be planned and managed so as to provide a sustained flow of products and services in successive rotations, according to a comprehensive long term management plan appropriate to the scale of operations and applicable to the Forest Management Unit (FMU), whether it belongs to a single owner or group of them.

2) Conservation of biological diversity: the use of forest resources shall be planned and managed so that the environmental values of the natural ecosystems contained in the FMU are protected and significant negative impacts on biodiversity are avoided.

3) Maintenance of resilience and productivity: forest resources shall be managed so as to maintain their health, vitality and productivity, by protecting them from fires and other damaging agents.

4) Conservation of soil and water: forest resources shall be managed so as to promote soil conservation and to minimize adverse impacts on the quantity and quality of water resources, taking particular account of the needs of downstream communities.

5) Sustainability of communities: forest managers shall respect the traditional and customary uses and rights of local communities, shall maintain good neighbourhood relationship with them and shall support the development of local capacities that contribute to the improvement of their quality of life.

6) Ethnic groups: forest managers shall take into account declared agreements, documented commitments and shall respect the legally established rights and the traditional knowledge of indigenous peoples to use and manage their lands and resources.

7) Labour conditions and rights: forest managers shall respect the rights of the forest workers, compensating them fairly and equitably, safeguarding their health and safety at work.
8) Laws, regulations, agreements and treaties: forest managers shall respect the laws of Chile and international agreements and legally biding treaties and shall take into consideration any other agreements and treaties, to which Chile is a signatory.

9) Monitoring and measurement: regular monitoring of the forest resources, the management system and the responsible companies and owners of the FMU shall be conducted with the purpose of evaluating the progress in achieving the stated principles.

\section{Criteria}

These are key elements, dimensions and processes that define, limit and permit the practical application of the principles. Through 43 criteria it is possible to evaluate periodically the management of the forests for sustainability, and therefore guarantee a true and constant improvement of the management practices.

\section{Indicators}

These are elements that can be described or measured quantitatively and qualitatively, to evaluate periodically their trend and verify in this way the level of compliance of a specific aspect of a criterion. There are a total of 190 indicators. For more information, please consult $w w w$. certfor.org or contact info@certfor.org.

\section{Assessment Process}

Every certification audit must begin with an opening meeting during which the lead auditor introduces the members of the team and confirms the following: audit plan; availability, roles and identities of any guides; formal communication documents; timetables and other relevant arrangements; method of reporting, including the grading of the audit findings; work site safety, emergency and security procedures; confidentiality matters; conflict of interests; information about any appeal system on the conduct or conclusions of the audit. After- 
wards, the program applicant makes a general presentation of the forest management unit. The presentation shall include historical data, details about the forest planning system, forest management objectives and silvicultural practices. Thereafter, the audit team selects which sites and people will be visited according to their respective fields of expertise, the magnitude of impacts associated to the company activities, the sites of special biological, cultural, environmental and economic significance, the sensitive issues, etc.

Auditors carry out verifications of both the office-based records of the company and their performance in the field. The audit team members, accompanied by their guides, disperse to the areas in which the activities are to be conducted. They must endeavour to obtain sufficient evidence so that significant individual findings and aggregates of less significant findings, both of which may affect any audit conclusions, are taken into account. On completion of the audit, the audit team reviews the findings and determines if the customer's system is suitable and effective in meeting the respective standard.

Also, a wide stakeholder consultation is carried out in relation to each forest management unit inspected. At least 30 days before the certification audit, a letter explaining the entire certification process and a questionnaire are sent to all relevant parties identified by the program applicant and agreed by the certification body. The survey includes questions on the existence of any present or past conflicts with the applicant, of any positive and/or negative aspects related to forest management performed on the FMU, special concerns, etc. Once all comments are received, a summary of stakeholders' opinions is prepared and used to schedule all the meetings. All concerns are recorded in a detailed audit report and must be followed over the years, but remain confidential in order to preserve stakeholders' rights.

This report is prepared according to a predefined format that is submitted to CertforChile for peer review and evaluation. The report includes a thorough description of the following items: the assessment process; the forest, its tenure and the socioeconomic and environmental contexts; a summary of the legislative, administrative and land use contexts; a general background about the operation; the forest management plan (including ownership and forest composition, forest management objectives, silvicultural and other management systems, harvesting techniques, sustained yield, rationale for annual harvest in terms of volume and species, safeguards for maintaining biodiversity, and plans for identification and protection of rare, threatened and endangered species); the stakeholder consultation process (including a list of all stakeholders influenced, summary of use-rights which relate to the land and forest, names and affiliations of people consulted during the evaluation, and a summary of main forest stewardship issues raised); audit results (strengths, weaknesses, opportunities for improvements, non-conformances); tracking, tracing and identification of logs; summary of nonconformances and corrective action requests.

This report is revised by at least two independent experts and by the FMU to be certified, which will have the right to make comments on the scores given and the other elements of the report. The auditing team will then publish a final report that takes into consideration the comments received, and recommend or refuse the certification of the FMU.

A minimum mean score of 3 for each principle is required to certify the FMU. However, no indicator must be marked with a nil score for the approval of the corresponding criterion or principle, and in the case where a criterion has been marked with a score of 2 the certification can be endorsed only if the FMU shows its commitment to correct all the main nonconformities that have been observed.

\section{Requirements for Public Consultation}

The CERTFOR audit process requires extensive stakeholder consultation by the auditors. Auditors must contact a range of stakeholders as broad as possible. Initial contact may be made by letter, telephone or e-mail. All stakeholders have the opportunity to request a meeting with the auditors.

CertforChile requires that certified companies make the management plan and the results of monitoring audits publicly available. CertforChile publishes the audit reports on its Web site.

\section{Chain of Custody}

Prior to the two-month Programme for the Endorsement of Forest Certification (PEFC) Chain of Custody (CoC) public consultation process that took place in summer 2004, CertforChile released its new CERTFOR CoC Standard Draft. This draft incorporates new requisites that match those of the latest PEFC International Chain of Custody Standard. While the document was sent to a wide range of stakeholders for comments, it remains available for consultation on the CERTFOR Web site (www.certfor.org). The final Standard should be published by late September 2004.

The principal objective of a Chain of Custody is to guarantee the connection between the flow of certified timber input directly to the output of products. To achieve a chain of custody and be able to label final products as certified, that is, sourced from a forest conforming to the SFM standard, each unit responsible for the timber — from the forest to the retail distribution channels - must possess a CoC certificate.

\section{A first in Chile: Arauco}

In December 2002, following a year working under the ISO 14001 environmental standard, Arauco's Environmental Management Committee decided to pursue certification for its forest management under the Chilean national CERTFOR standard.

The first preliminary audit, conducted in January 2003, with the technical assistance from CERTFOR, enabled Arauco to prepare an exhaustive gap analysis of progress made in compliance with the Standard versus where it needed to be. This analysis involved more than 80 professionals from Arauco's divisions.

In March of that same year a new performance evaluation was enabled to embrace the most critical areas. Sixteen internal CERTFOR auditors were trained to perform the subsequent internal compliance audit processes for monitoring progress with the implementation plan. In addition, environmental training of personnel was performed during the process and approximately 3000 employees received SFM training.

Following these internal audits, Arauco selected QMI - A Division of CSA Group to conduct the certification audits. QMI, North America's leading management systems registrar, has gained vast experience since its foundation in 1984 and has issued thousands of certificates for standards such as ISO 9001 and ISO 14001, QS 9000, TS 16949, AS 9000, TL 9000, OHSAS 18001, CAN/CSA Z809, CSA Plus 1163 CoC and SFIS 
Well known for its high value-added services, QMI is proud to work with major forest companies such as Abitibi-Consolidated, Domtar, Norbord, Tembec, UPM-Kymmene, Western Forest Products and Weyerhaeuser among others.

CERTFOR and QMI cooperatively chose an audit team in accordance with CertforChile procedures. The audit team included Francis Dubé, a full-time QMI auditor and an expert in agroforestry and soil protection as lead auditor; Ramiro Morales, an expert in forest economics and planning; Juan Francisco Ojeda, a local specialist in social matters and indigenous affairs; and Ander Uriarte, a local specialist in biodiversity and silviculture. All of the team members are registered professional foresters. An independent Chilean legal adviser and lawyer, Christian Figueroa, was also consulted for environmental and forestry related issues.

The certification audit, completed in June 2003, lasted 27 auditor days. A survey of 130 interested parties was conducted using a written questionnaire. A total of 97 people were interviewed during the audit, including workers and independent contractors, neighbours, urban and rural community representatives, mayors, indigenous people, public sector professionals, school and college teachers and students, police officers and firefighters, physicians and nurses, NGOs, and more.

The activities and sites visited were chosen carefully by the audit team members according to their respective expertise and knowledge of sensitive issues and corresponding to representative samples of the company's operations and forestlands. A summarized description of the assessment process for each principle is presented as follows (QMI - A Division of CSA Group 2003b, 2003c, 2003d).

For principle 1, the lead auditor and the expert in forest economics interviewed thoroughly and verified evidences with the respective division general managers, corporate managers of development for the long term planning, finance and administration, and personnel from the regional planning, mensuration and mapping units.

Principle 2 was assessed by the lead auditor and the expert in biodiversity, for which they audited the personnel of the mensuration, mapping, roads and harvesting units, as well as Bioforest S.A., a scientific entity belonging to Forestal Arauco and responsible for research and development for the three forestry divisions. Criteria and indicators were reviewed both in the different offices and in the field, where protected and conservation areas, reserves, biological corridors, recreational parks and interpretation centers were visited. This also included special protection areas for restoration of threatened and endangered species.

Principle 3 was verified in the offices, tree nurseries, disease and insect control units, and fire fighting headquarters. Young and mature radiata pine and Eucalyptus globulus plantations were visited afterwards. Principle 4 involved personnel of road, harvesting and transport units and Bioforest S.A. Several techniques of land preparation, harvesting and skidding as well as control of water deficit and reclamation of degraded lands were assessed. Various evidences supporting these principles were also collected since 2001 during the ISO 14001 audits.

With respect to principles 5, 6 and 7, the lead auditor and the specialist in social matters interviewed a number of workers and contractors from different sectors and operations of each forestry division, native people including a Mapuche Chief, and diverse interested parties including municipalities and rural communities, neighbours' unions, NGOs, school boards and universities. Personnel of the occupational health and safety unit were also audited.

For principle 8, the lead auditor, who had been advised by the local legal expert since the ISO 14001 initial certifications, verified the systems in place to identify and ensure access to the applicable legislations, regulations, agreements, treaties and other requirements.

Finally, every team member assessed Principle 9 throughout the audit. Regional and corporate managers, supervisors and other personnel, including Bioforest S.A. participated in the process. Models for calculating the annual carbon uptake and systems to determine carbon stored in the company's forestland were verified. The lead auditor also analyzed the procedure of tracking and accounting for wood flows originating from the Forest Management Units (FMU) to mill gates.

Afterwards, the lead auditor prepared the certification reports, with the advice of every team member. Thereafter, CERTFOR examined the reports and then a panel of three expert peer reviewers named by CERTFOR (two Chilean and one European), revised them. With this information, the Board of CertforChile recommended certification.

Following this process, QMI issued a CERTFOR certificate for the 926900 ha owned by Forestal Arauco S.A. and its three subsidiaries, Forestal Celco and Forestal Cholguán (446 100 ha), Bosques Arauco (257 300 ha) and Forestal Valdivia (223 500 ha). The total area is comprised of 644500 ha of Pinus radiata and Eucalyptus species with an estimated annual yield of $8100000 \mathrm{~m}^{3}$ and $1700000 \mathrm{~m}^{3}$ respectively over the next five years, which represent almost $35 \%$ of Chile's plantations; of 220200 ha of natural forests, mostly Nothofagus species and permanent protection areas; and of 62200 ha of agricultural and general use lands.

The CERTFOR sustainable forest management certificate is valid for five years. The organization is annually subjected to surveillance/follow-up audits to check that the Standard performance level is maintained.

\section{Conclusion}

After being launched more than two years ago, CERTFOR is gaining respect in Chile and is being accepted by a larger number of supporters. CERTFOR has been a member of the Programme for the Endorsement of Forest Certification schemes (PEFC) formally known as the Pan European Forest Certification since November 2002. In early 2004, the PEFC started a public consultation period for the assessment of CERTFOR. Once completed, it will be the first non-European Forest Certification Standard to be recognized by PEFC. As a comparison, the Canadian Standards Association has just submitted application for its SFM Standard CAN/CSA Z809-02 and expects to obtain PEFC endorsement by early 2005.

CertforChile is developing a second scheme, the Standard for Natural Forests, which should be delivered during 2004-2005. Simultaneously, other environmental NGOs such as CODEFF are supporting the Chilean Initiative for Forest Certification (ICEFI), which is currently following a participative process. It has not yet reached a conclusion. ICEFI is also working on obtaining recognition as the FSC national initiative. It appears lately that CERTFOR and ICEFI are considering a convergence of these initiatives for natural forests.

Group certification for small forest owners also constitutes a viable alternative for those who cannot afford the cost of indi- 
vidual certification audits. The CERTFOR group standard is being implemented with a few groups within the country, and the first certifications are expected to occur within the end of 2004 (CertforChile 2003b).

Other forest companies are following Arauco's foot steps. Among them is Bosques de Chile S.A. with its 25240 ha, which was verified by QMI in October 2003. It was successful in achieving certification in February 2004.

Once PEFC completes the assessment of the Standard, it will likely attract more enthusiastic organizations seeking the European markets. In addition, since Chile joined the North American Free Trade Agreement in January 2004, a mutual recognition with the CAN/CSA Z809, ATFS and SFI standards could also eventually be expected.

\section{Acknowledgements}

The authors wish to thank CertforChile for the information provided and Dr. H. J. van Hensbergen for his assistance.

\section{References}

Cashore, B. and C. McDermott. 2004. BC forest report: Comparing British Columbia with the world. In: Global environmental forest policies: Canada as a constant case comparison of select forest practice regulations. $12 \mathrm{p}$. (www.ifor.ca or www.bcforestinformation.com)

CertforChile. 2003a. CERTFOR Estándar de manejo forestal sustentable en Chile: Plantaciones. 35 p.

CertforChile. 2003b. CERTFOR Estándar para certificación en grupo. $11 \mathrm{p}$.

Canadian Standards Association. 2002. CAN/CSA Z809-02

Sustainable forest management: Requirements and guidance. $51 \mathrm{p}$.

QMI - A Division of CSA Group. 2003a. QMInside November Edition. 8 p.

QMI - A Division of CSA Group. 2003b. Reporte de auditoría CERTFOR : Forestal Celco S.A. \& Forestal Cholguán S.A. 34p. (www.certfor.org/archivos/Sistema/qmi.htm)

QMI - A Division of CSA Group. 2003c. Reporte de auditoría CERT-

FOR : Bosques Arauco S.A. 35p. (www.certfor.org/archivos/ Sistema/qmi.htm)

QMI - A Division of CSA Group. 2003d. Reporte de auditoría CERT-

FOR : Forestal Valdivia S.A. 36p. (www.certfor.org/archivos/ Sistema/qmi.htm) 